\title{
22. The Travelling Story of Pettersson in the Pacific
}

Anette Nyquist

Social Anthropology, Stockholm University

Some stories travel better than others. Consider the true story of Carl-Emil Pettersson, a young man who, at I7, leaves his home in rural Sweden and went to sea. He survives a ship-wreck in the Pacific, settles on the small island where is washed up, marries the local princess and strikes it rich in gold findings. That story is a well-travelled one.

The aim of this chapter is to show how the story of Pettersson's life not only endures extensive geographical and temporal travels but also, on its way through time and space, traverses multiple literary genres as well as forms of media. I use the story of Pettersson as an illustrative example of my suggestion that travelling stories play significant roles in processes of world-making. The world that the story of King Karl Pettersson I, in combination with its intriguing sequential narrative, assist in making is the persistent one of life in Oceania as "Paradise on Earth". This chapter points to the significant roles that media and narratives have in processes of world-making. It takes as its theoretical point of departure, Nelson Goodman's seminal work Ways of Worldmaking and builds on how others point to the intricate relationship between narratives and media in processes of world-making.

${ }^{1}$ Nelson Goodman, Ways of Worldmaking (Indianapolis: Hackett, I978).

How to cite this book chapter:

Nyqvist, Anette. "The Travelling Story of Pettersson in the Pacific". In World Literatures: Exploring the Cosmopolitan-Vernacular Exchange, edited by Stefan Helgesson, Annika Mörte Alling, Yvonne Lindqvist, and Helena Wulff, 26I-274. Stockholm: Stockholm University Press, 20I 8. DOI: https:// doi.org/IO.I6993/bat.v. License: CC-BY. 
However, I here first turn to the literature on the world-making capacity of travel writing because, while this chapter points to the role that travelling stories have in processes of world-making, the larger project - through which the story of Pettersson suddenly came sailing - concerns the world-making capacity of travel writing.

\section{Travel Stories and World-Making}

Travel writing is a genre inherently difficult to define and classify. Travel stories, both oral and written, have been around for thousands of years and is one of the world's oldest and most widely dispersed forms of literature. It is a genre that has no national boundaries but, rather, claims to be cosmopolitan by definition. ${ }^{2}$ As a particular corpus travel writing is a socially important literary genre and it has been far more influential in shaping perceptions of people and places than scholarly ethnographic publications. ${ }^{3}$ Already during the tenth century travel narratives were seen as an important and influential literary genre outside the western world. The medieval Moroccan traveller and scholar Ibn Battuta is a point in case. ${ }^{4}$ From a western perspective some of the earliest travel accounts are from the European explorers' reports of their discoveries and encounters in and of the world. ${ }^{5}$ From Edward Said's Orientalism and on, we know that travel writing does not consist simply of factual accounts but, rather, often furthers exoticism and domination through textual (mis)representation. ${ }^{6}$ Travel stories "reflect the conditions and

2William Dalrymple, "Home Truths Abroad", The Guardian, I9 September 2009; Tim Youngs, The Cambridge Introduction to Travel Writing (Cambridge: Cambridge University Press, 2013).

3 Hussein M. Fahim, "European Travellers in Egypt: The Representation of the Host Culture," in Travellers in Egypt, ed. P. Starkey and J. Starkey (London: I. B. Tauris, I998); Youngs, The Cambridge Introduction.

4 Paul Zumthor and Catherine Peebles, "The Medieval Travel Narrative", New Literary History 25.4 (I994): 809-24; Youngs, The Cambridge Introduction.

5 Maria Pretzler. Pausanias. Travel Writing in Ancient Greece (New York: Bloomsbury, 2013); Youngs The Cambridge Introduction.

${ }^{6}$ Edward Said, Orientalism (New York: Random House, I978); Daniel 
attitudes that exist in the traveller's home culture" 7 and, thus, "travellers have already been influenced, before they travel, by previous cultural representations that they have encountered". ${ }^{8}$

Travel stories from the large area now commonly called Oceania typically lump together the 30000 islands scattered in the in the Pacific Ocean and turn them into an idea rather than a geographical location. ${ }^{9}$ The consistent story that is told, by western travellers, from here is that life on the islands of Oceania is "Paradise on Earth". This notion was created as soon as western travellers went to the area and wrote home about it. This world-making, then, began with the travelogues of the eighteenth-century European explorers. The "South Seas" became the great frontier of romantic imagination as well as of modern science, and the allure of the area acquired utopian connotations. ${ }^{\circ}$ One of the earliest written accounts is from I768 when French explorer Louis Antoine de Bougainville spent ten days in what is now known as Tahiti and reports how he thought he "had been transported into the garden of Eden" ${ }^{\text {II }}$ Bougainville soon learned that the island was not quite the paradise that he at first imagined, but his journal's depictions of an erotic paradise with its enticing pairing of native beauty and free love endured. ${ }^{\mathrm{I} 2}$ Such exoticised and romanticised stories of life in Oceania are consistently nurtured and reproduced.

In a general sense, it has been suggested that literary products are key elements in the configuration of the world itself. ${ }^{\mathrm{I} 3}$ Scholars

Martin Varisco, Reading Orientalism: Said and the Unsaid (Seattle: University of Washington Press. 2007).

7 Youngs, The Cambridge Introduction, 165.

8 Youngs, The Cambridge Introduction, 9.

9 Anders Mathlein, Senare i Söderhavet. Öar $i$ drömmen och samtiden (Stockholm: Carlssons bokförlag, I994).

to Felipe Fernández-Armesto, "Reviews", Journeys 3, no. 2 (2002): I25-28.

II Louis-Antoine de Bougainville. A Voyage round the World: Performed by Order of His Most Christian Majesty, in the Years I766, I767, I768, and I769. Translated by J. R. Forester (London: J. Nourse Bookseller to His Majesty \& T. Davies Bookseller to the Royal Academy, I772), 228-29.

12 Joyce Appleby, Shores of Knowledge. New World Discoveries and the Scientific Imagination (New York: W.W. Norton \& Co. 2013), I92.

13 Eduardo Archetti, Exploring the Written. Anthropology and the Multiplicity of Writing (Oslo: Scandinavian University Press, 1994). 
of travel literature pose the question: "How does travel literature produce "the rest of the world" ? ${ }^{14}$ or, put differently, what role do travel stories play in processes of world-making? Peter Bishop answers that question with the assertion that: "Travel writing creates worlds, it does not simply discover them". ${ }^{\text {is }}$ World-making thus starts, according to Goodman, from worlds already known; in other words: "the making is a remaking". ${ }^{16}$

This brings us straight to the roles that different forms of media and stories, or narratives, have in processes of world-making. Media play an important part here and the role of media, medialisation and the dynamics of pre- and remediation are seen as important factors that have shaped, and continue to shape, our ways of world making". ${ }^{17}$ More specifically, inter- and transmedial adaptations and connections are key drivers in processes of world-making. This means that an assortment of different media, such as literary texts, newspaper articles, TV-programmes and more, together play significant parts in the making of worlds. ${ }^{18} \mathrm{In}$ conjunction with this, the complexity of narrative world-making deserves to be mentioned because the narrative is a powerful way of world-making. The main reason for this is that the narrative and storytelling - that is the procedures and processes through which happenings, occurrences, or incidents become meaningful events, stories, and story-worlds - not only generates possible worlds, narratives also exert performative power. ${ }^{19}$

${ }^{14}$ Mary Louise Pratt, Imperial Eyes. Travel Writing and Transculturation (London: Routledge, I992).

I5 Peter Bishop, “The Geography of Hope and Despair: Peter Matthiessen's The Snow Leopard", Critique 26, no. 4 (I985): 204.

i6 Goodman, Ways of Worldmaking, 6.

${ }_{17}$ Ansgar Nünning and Vera Nünning, "Ways of Worldmaking as a Model for the Study of Culture: Theoretical Frameworks, Epistemological Underpinnings, New Horizons", in Cultural Ways of Worldmaking. Media and Narratives, eds. Nünning et al. (Berlin: de Gruyter, 2010), 4.

I8 Birgit Neumann and Martin Zierold, "Media as Ways of Worldmaking: Media-specific Structures and Intermedial Dynamics”, in Cultural Ways of Worldmaking: Media and Narratives, ed. Nünning et al. (Berlin: de Gruyter, 2010), 103-I 8 .

19 Ansgar Nünning, "Making Events - Making Stories - Making Worlds: Ways of Worldmaking from a Narratological Point of View”, in Cultural 


\section{The Story of Pettersson and Its Travels}

Now to the well-travelled story of Carl-Emil Pettersson, how it contributes to the construction on life in Oceania as Paradise on Earth and why this particular travelling story has come to shape the notion of life in the South Seas for generations of Swedes.

Carl-Emil Pettersson, the story goes, ${ }^{20}$ was born in October I 875 in the, then, small rural community of Sollentuna, just north of Stockholm. I7 years old he left home for work on board naval and merchant ships. Little was known of Pettersson after his departure in I 892 until one day, I 5 years later, he showed up at his mother's door in Stockholm. Pettersson had during those years worked on merchant ships in the Bismarck Archipelago northeast of New Guinea in the western Pacific. ${ }^{21} \mathrm{He}$ had survived multiple dramatic ship wrecks and in 1905 he washed up on one of the Tabar Islands where he remained, acquired land and started a coconut palm plantation, became friends with the local chief, Lamry, and fell in love with his daughter, Singdo-Misse. After his brief visit in Stockholm Pettersson returns to Tabar and continues his life there. He marries Singdo-Misse and their first child is born I910. ${ }^{22}$

Ways of Worldmaking: Media and Narratives, ed. Nünning et al. (Berlin: de Gruyter, 20IO), I9I-2I4.

20 See for example: Unsigned article "Från signalmatros till negerprins och plantagekung”, Dagens Nyheter, I7 September I922; A handwritten note, signed J. Blees and dated May 24 I924 containing Petterson's biographical data. Note available in the archives of The Museum of World Culture, Gothenburg; "Svenska öden och äventyr i främmande land", Allsvensk Samling, I5 May I924. Clipping available in the archives of The Museum of World Culture, Gothenburg and Joakim Langer and Hélena Regius, Kung Kalle av Kurrekurreduttön. En resa i Efraim Langstrumps fotspår (Stockholm: Forum, 2002).

${ }_{21}$ The region was at the time under German colonial rule.

${ }^{22}$ Hélena Regius, "Carl Emil Pettersson I875-1937", in Kung Kalle av Kurrekurreduttön. En resa $i$ Efraim Langstrumps fotspår, co-written with Joakim Langer (Stockholm: Forum, 2002), has thoroughly researched and accounted for the life story of Pettersson. In later editions (according to personal communication 29 March 20I7) anthropologist Hélena Regius is referenced as being the author of this chapter in the book. 
It is not until I9I4 that the story of Carl Emil Pettersson becomes publically known in Sweden as the count, diplomat and author Birger Mörner (1867-1930) writes about it in a travel book. In I9I 3 Birger Mörner conducts his third trip to the South Seas and meets Pettersson and his family in their home on Tabar. Mörner's book about his travels in the eastern New Guinea and surrounding island, Aráfis tropiska $\stackrel{0}{{ }^{2},{ }^{23}}$ is published in I9I4. Mörner - or rather his alter ego Aráfi - does not, however, pay much attention to Pettersson but dedicates a chapter to Petterson's wife, Singdo-Misse, and her stories. It is only at the very end of the chapter that Mörner mentions Pettersson in a short note. ${ }^{24}$ The chapter is accompanied by a photograph of Carl Emil Pettersson and his wife, Singdo-Misse, both dressed in traditional Swedish costumes and surrounded by two of their children. In November I 9 I 4 Birger Mörner holds a public lecture in Stockholm about his travels and the largest daily newspaper, Dagens Nybeter, prints a report from the event. Carl Emil Pettersson's story is prominently featured, complete with Mörner's photo of the couple in Österåker-costumes, under the headline: "A Stockholm boy on the South Sea islands". ${ }^{25}$ It tells the story of how "Kalle Pettersson" was shipwrecked in the South Sea, settled on the island of Tabar, married a local woman with whom he has several children and how he, because of his body and strength is called "The Strong Charley". The story of Pettersson, not least with the assistance of the photograph, gains a lot of attention in Sweden at the time and he becomes a national celebrity. ${ }^{26}$

Singdo-Misse dies I92 I soon after giving birth to the couple's ninth child and Pettersson travels to Sweden on a mission to find a second wife. ${ }^{27}$ Chief Lamry of Tabar has by this time also passed away and Swedish media now write about Carl Emil Pettersson

\footnotetext{
${ }^{23}$ Birger Mörner, Aráfis tropiska år (Stockholm: P. A. Norstedts \& söners förlag, I9I4), 208-I6. Book title in translation: "Aráfi's tropical years".

24 Mörner, Aráfis tropiska år, 2 I 6.

25 "En Stockholmspojke på Söderhavsöarna”, Dagens Nyheter, I I November I9I4.

${ }^{26}$ Regius, "Carl Emil Pettersson," I I 7-2 I.

27 Regius, "Carl Emil Pettersson”, I I 7-2 I.
} 
as royalty. ${ }^{28}$ Several of the published stories of Pettersson's life on Tabar build on letters that Pettersson himself has written to editors and prominent figures in Sweden. ${ }^{29}$ During the early I920s there are plenty of stories of "Prince Pettersson", "King Carl I" and, since he does find a Swedish woman to marry - and bring back to Tabar - during his visit, she, Jessie Simpson from Gävle, becomes "Princess" and "Queen Pettersson" in the Swedish press. ${ }^{\circ}$ By the I930s Carl Emil Pettersson has become a media personality in Sweden. Events in his life on the islands in the western Pacific are printed as news in Swedish press and his life story is told and re-told in so-called women's magazines such as Husmodern and Vecko-Journalen. ${ }^{31}$ Over the years Swedish readers learn that Pettersson's coconut palm business is crumbling, that both he and his new wife have fallen ill in malaria and other tropical diseases, that Pettersson has found gold on his land on one of the Tabar islands, that he wants to sell his estate and business and move back to Sweden, that "Queen" Jessica has returned to Sweden for medical reasons, that she dies in Stockholm in May I935 and that Carl Emil Pettersson, "King of Tabar", himself dies of a heart attack in Sydney, Australia May I937. ${ }^{22}$ It is now that the travelling story of Pettersson in the Pacific takes a new turn.

\section{Travelling to Fiction}

Who does Carl Emil Pettersson resemble if not the incredibly strong, rich in gold, King of an island in the South Seas: Captain

${ }^{28}$ See for example: "Från signalmatros till negerprins och plantagekung", Dagens Nyheter, I7 September I922; "Prins Pettersson av Fisher Island," Dagens Nyheter, 24 September I922; "Svenska öden och äventyr i främmande land", Allsvensk Samling, I 5 May I924.

29 Some of these letters are available in the archives of The Museum of World Culture, Gothenburg, filed as: "Documents concerning collection 35.27.I-I 2., s.c. malingans from Tabar.”

30 Regius, "Carl Emil Pettersson," I I6-57, and Langer and Regius, "Kung Kalle", г 87-88.

${ }^{31}$ See especially: Thyra Ekegårdh, "Svenskan som blev drottning på en Söderhavsö”, Husmodern, June I6, I935.

32 Regius, "Carl Emil Pettersson", I 52-65. 
Ephraim Longstocking, Pippi Longstocking's seafaring father? Pippi Longstocking is, of course, the main character in Swedish author Astrid Lindgren's popular children's books about is the clever and independent girl in red braids and odd clothes who has superhuman strength, unlimited funds and lives by herself - with her horse and monkey - in a large house in a small town somewhere in Sweden. Her mother is "an angel in heaven" and her father is a seafaring Captain who, after a shipwreck in the Pacific washed ashore on a small island where he remained and eventually became King. ${ }^{33}$

It was a Swedish author, Joakim Langer, who in the year 2000 made the connection and "found" Pippi's father. In his basement Langer came upon a short newspaper clipping from I935 stating that "King Karl I Pettersson sells his Kingdom". ${ }^{34}$ Having, like most Swedes, grown up with the stories of Pippi Longstocking Langer immediately recognised the striking resemblances between Carl Emil Petterson and Ephraim Longstocking, Pippi's father. ${ }^{35}$ Langer's theory is that Astrid Lindgren (1907-2002) must have read about, and been inspired by, Carl Emil Pettersson's life story in Swedish press and then, later, built her fictional character Ephraim Longstocking on Pettersson's story. Langer tries to get this confirmed from Lindgren herself but in early $200 \mathrm{I}$ she is not healthy enough to recall or respond. He does reach Lindgren's sister, Stina, who confirms that she read about King Pettersson growing up. ${ }^{36}$

Astrid Lindgren created and developed the characters and adventures of Pippi Longstocking in I94 I as she told stories to

${ }_{33}$ Lindgren, Astrid. "Astrid Lindgren berättar om sig själv”, in En bok om Astrid Lindgren, ed. M. Ørvig. (Stockholm: Rabén \& Sjögren, I977); Lundqvist, Ulla. Århundradets barn. Fenomenet Pippi Långstrump och hennes förutsättningar (Stockholm: Raben \& Sjögren, I979); Metcalf, Eva-Maria. "Tall Tale and spectacle in Pippi Longstocking," Children's Literature Association Quarterly I 5 , no. 3 (I990): I30-35.

34 Joakim Langer, “Joakims berättelse”, in Kung Kalle av Kurrekurreduttön. En resa $i$ Efraim Långstrumps fotspår, co-written with Hélena Regius (Stockholm: Forum, 2002), I 2.

35 Langer, "Joakims berättelse", I I-24.

${ }^{36}$ Langer, "Joakims berättelse", I 5; Regius, "Carl Emil Pettersson," I 33. 
cheer up her young daughter, who was suffering from pneumonia. Lindgren did not write down the stories of Pippi until I944 when she herself became ill and had to be still. ${ }^{37}$ After having been rejected by one publishing house, another publisher took on Lindgren and issued Pippi Langstrump late in I945, soon to be followed by Pippi goes aboard in 1946 and Pippi in the South Seas in I 948..$^{8}$ Pippi's seafaring father Captain Ephraim Longstocking, King of Kurrekurredutt Isle in the South Seas, is more properly introduced to the readership in Lindgren's second and third books about Pippi. All in all Lindgren has published 15 books about Pippi Longstocking and, based on sales, these are the most popular of her work. The Pippi books have been translated into 70 languages and sold in 60 million copies worldwide. ${ }^{39}$ Lindgren's Pippi adventures have been adapted into various TV-series and feature films both in Sweden and many other countries. Children all over the world and particularly in Sweden have, quite literally, grown up with the stories of Pippi Longstocking and come to well know her adventures, not least the ones where she sets off to look for - and find - her distant father Captain Ephraim Longstocking who is living on an island in the South Seas. ${ }^{4}$

The articles about Carl Emil Pettersson, as readers will have noticed, as well as, to some extent, Lindgren's books about Pippi in the South Seas are no exceptions from the exoticising and romanticising, stereotypical and outright racist descriptions and depictions of the people of, and life on, the islands in the western Pacific. Granted, the children's book from I948, it should be noted, does not contain any reference to sexual license. But the notion of island life as idyllic, blissful and naturally opulent is

37 Jens Andersen, Denna dagen, ett liv: en biografi över Astrid Lindgren (Stockholm: Norstedts, 20I4); Margareta Strömstedt, Astrid Lindgren: en levnadsteckning (Stockholm: Raben \& Sjögren, 2007).

${ }^{38}$ In translation: Pippi Longstocking, Pippi goes aboard and Pippi in the South Seas.

39 astridlindgren.se, accessed April I, 2017, http://www.astridlindgren.se.

40 The TV-series Pippi Langstrump, aired in SwedenI969 together with the major feature film Pippi Langstrump på de sju haven [transl. Pippi Longstocking on the Seven Seas) from I970, were both critically acclaimed and immensely popular. 
there, as well as the colonial, and racist, representations of "the natives". In the new 2015 edition of the first three Pippi books racist dialogue was edited out as was dialogue from the 2014 edition of the I960s TV-series. ${ }^{41}$

Back to Langer's "discovery" of the real life model of Ephraim Longstocking. In $200 \mathrm{I}$ he sets out on a search both for more information on Pettersson and for collaborators on a trip to Tabar island to look for traces of Pettersson. Langer gets in touch with anthropologist Hélena Regius who, as part of her research on Malangan art and ceremonies in Melanesia, ${ }^{42}$ already had tracked down Pettersson's story and relatives in Australia, Papua New Guinea and Tabar Island. ${ }^{43}$ Langer contacts media, find sponsors and collaborators and soon he two of his co-workers, Hélena Regius and a journalist travel to Tabar Islands to talk to relatives of Pettersson/ Longstocking. ${ }^{44}$ Upon their return, in April 200I, media scramble for the story of how the father of Pippi Longstocking is "found". 45 Langer and Regius are interviewed in national and international media, ${ }^{46}$ they soon get a book deal and publish their book Kung

${ }^{4}$ L Lotta Olsson, “'Negerkung' tas bort i nya Pippi”, Dagens Nyheter, February I 4, 20I 5; Kim Veerabuthooro Nordberg, "SVT rensar ut rasismen ur Pippi Långstrump”, SVT Nyheter, 29 September 20I4, accessed I April 20I7: http://www.svt.se/kultur/svt-rensar-ut-rasismen-ur-pippi-langstrump.

${ }^{42}$ Intricate figures carved out of wood made for ceremonial use. Carl Emil Pettersson had, upon request, sent several malangans to Sweden. "The Pettersson malangans" have, on several occasions, been in exhibit at Swedish museums and are now kept in storage at The Museum of World Culture, Gothenburg.

43 Hélena Regius, "Hélenas berättelse”, in Kung Kalle av Kurrekurreduttön. En resa $i$ Efraim Långstrumps fotspår, co-written with Hélena Regius (Stockholm: Forum, 2002), 25-35, and personal communication 29 March 2017.

${ }_{44}$ Joakim Langer, "Resan", in Kung Kalle av Kurrekurreduttön. En resa $i$ Efraim Långstrumps fotspår, co-written with Hélena Regius (Stockholm: Forum, 2002), 39-59.

45 Rolf Broberg, "Kurrekurreduttön i verkligheten”, Dagens Nyheter, 29 April 200I; "Här är Pippis riktiga pappa. Carl E Pettersson var Kungen i Söderhavet”, TT/Aftonbladet, 29 April $200 \mathrm{I}$.

${ }^{46}$ Joakim Langer, "Vad hände sedan? I937-2002", in Kung Kalle av Kurrekurreduttön. En resa $i$ Efraim Långstrumps fotspår, co-written with Hélena Regius (Stockholm: Forum, 2002), I76. 
Kalle av Kurrekurreduttön. En resa $i$ Efraim Långstrumps fotspår, ${ }^{47}$ Langer writes his own children's book on the theme: Kapten Kalle på de sju haven, ${ }^{48}$ Regius and Langer tour the country and hold public lectures about the Pettersson/Longstrump story, they are contracted by a travel company and return to the Tabar Islands with a group of tourists, there is an exhibit at The Museum of Ethnography in Stockholm and Langer signs a feature film contract for the Pettersson/Longstocking story with a major filmmaker. ${ }^{49}$

\section{Travelling Stories and the Making of Worlds}

Carl Emil Pettersson's life in the Bismarck Archipelago northeast of New Guinea in the western Pacific became well known since his story, as I have here shown, was featured in a travel book in I9I4 and then circulated in the Swedish print media between I9I4 and I937. Pettersson's life story was subsequently, through Astrid Lindgren's creation of Ephraim Longstocking, transposed into fiction and circulated once again, this time it travelled to even more forms of media such as TV-series and feature films. The story travelled to other geographical locations when Lindgren's books, as well as TV-series and feature films, were translated into other languages. With the connection of Carl Emil Pettersson to Ephraim Longstocking the story took a new journey and their joint story travelled through all forms of mass media in multiple languages and geographical settings, it travelled to non-fiction and fiction literature, and it travelled such diverse textual contexts as museum exhibits and travel catalogues.

The story of Pettersson/Longstocking and his life on an island in the Pacific has by now travelled for more than roo years, all over the world and across literary genres and through various forms of media. Along the way there have been adaptations, adjustments and editing of the story but the idealised, romanticised and

47 Langer and Regius, Kung Kalle (2002)

${ }^{8}$ Joakim Langer and Martin Trokenheim, Kapten Kalle på de sju haven, (Stockholm: Forum, 2002).

49 Langer, "Vad hände sedan?", I80-85. The feature film is later "put on ice" and has yet to be made. 
exoticised descriptions and depictions of life in Oceania remain intact and immovable throughout the travels.

And this well-travelled story keeps on moving - now it is at the core of a chapter in an anthology on literature and world-making published by Stockholm University Press. My point here, with the assistance of Carl-Emil Pettersson and Ephraim Longstocking, is to show that stories, or narratives, and various genres and forms of media play significant roles in processes of world-making.

\section{Bibliography}

Andersen, Jens. Denna dagen, ett liv: en biografi över Astrid Lindgren. Stockholm: Norstedts, 2014.

Appleby, Joyce. Shores of Knowledge. New World Discoveries and the Scientific Imagination. New York: W.W. Norton \& Co., 2013.

Archetti, Eduardo. Exploring the Written. Anthropology and the Multiplicity of Writing. Oslo: Scandinavian University Press, I994. astridlindgren.se, accessed I April 20I7, http://www.astridlindgren.se. Bishop, Peter. “The Geography of Hope and Despair: Peter Matthiessen's The Snow Leopard," Critique 26, no. 4 (I985): 203-I6.

Bougainville, Louis-Antoine de. A Voyage round the World: Performed by Order of His Most Christian Majesty, in the Years I766, I767, I768, and I769. Translated by J. R. Forester. London: J. Nourse Bookseller to His Majesty \& T. Davies Bookseller to the Royal Academy, I772.

Broberg, Rolf. “Kurrekurreduttön i verkligheten”. Dagens Nyheter, 29 April 200I.

Dalrymple, William. "Home Truths Abroad". The Guardian, I9 September 2009 .

"En Stockholmspojke på Söderhavsöarna”. Dagens Nyheter, I I November I9I4.

Fahim,Hussein, M. "European Travellers in Egypt: The Representation of the Host Culture". In Travellers in Egypt, edited by P. Starkey and J. Starkey. London: I. B. Tauris, I998. 
Fernández-Armesto, Felipe. "Reviews". Journeys 3, no. 2 (2002): I 25-28.

"Från signalmatros till negerprins och plantagekung". Dagens Nyheter, I7 September 1922.

Goodman, Nelson. Ways of Worldmaking. Indianapolis: Hackett, I978.

"Här är Pippis riktiga pappa. Carl E Pettersson var Kungen i Söderhavet”. TT/Aftonbladet, 20 April 200 I.

Langer, Joakim and Hélena Regius. Kung Kalle av Kurrekurreduttönen resa i Efraim Långstrumps fotspår. Stockholm: Forum, 2002.

Langer, Joakim and Martin Trokenheim, Kapten Kalle på de sju haven, Stockholm: Forum, 2002.

Lindgren, Astrid. “Astrid Lindgren berättar om sig själv”. In En bok om Astrid Lindgren, edited by M. Ørvig. Stockholm: Rabén \& Sjögren, I977.

Lundqvist, Ulla. Århundradets barn. Fenomenet Pippi Långstrump och hennes förutsättningar. Stockholm: Raben \& Sjögren, I979.

Mathlein, Anders, Senare i Söderhavet. Öar i drömmen och samtiden. Stockholm: Carlssons bokförlag, I994.

Metcalf, Eva-Maria. "Tall Tale and Spectacle in Pippi Longstocking," Children's Literature Association Quarterly I5, no. 3 (I990): I $30-35$.

Mörner, Birger. Aráfis tropiska år. Stockholm: P. A. Norstedts \& söners förlag, I9I4.

Neumann, Birgit and Martin Zierold. "Media as Ways of Worldmaking: Media-Specific Structures and Intermedial Dynamics”. In Cultural Ways of Worldmaking: Media and Narratives, edited by Nünning et al., го3-г 8. Berlin: de Gruyter. 20 го.

Nordberg, Kim Veerabuthooro. "SVT rensar ut rasismen ur Pippi Långstrump”. SVT Nyheter, 29 September 20I4, accessed I April 20I7, http://www.svt.se/kultur/svt-rensar-ut-rasismen-ur-pippi-langstrump.

Nünning, Ansgar. "Making Events - Making Stories - Making Worlds: Ways of Worldmaking from a Narratological Point of 
View". In Cultural Ways of Worldmaking: Media and Narratives, edited by Nünning et al., I9I-2I4. Berlin: de Gruyter. 20 IO.

Nünning, Ansgar and Vera Nünning. "Ways of Worldmaking as a Model for the Study of Culture: Theoretical Frameworks, Epistemological Underpinnings, New Horizons”. In Cultural Ways of Worldmaking. Media and Narratives, edited by Nünning et al., I-25. Berlin: de Gruyter, 2010.

Olsson, Lotta. “'Negerkung' tas bort i nya Pippi”. Dagens Nyheter, I 4 February 20I 5.

Pratt, Mary Louise.Imperial Eyes. Travel Writing and Transculturation. London: Routledge, I992.

Pretzler, Maria. Pausanias. Travel Writing in Ancient Greece. New York: Bloomsbury, 2013.

"Prins Pettersson av Fisher Island". Dagens Nyheter, 24 September I922.

Said, Edward. Orientalism. New York: Random House, I978.

Strömstedt, Margareta, Astrid Lindgren: en levnadsteckning, Stockholm: Raben \& Sjögren, 2007.

“Svenska öden och äventyr i främmande land". Allsvensk Samling, I 5 May I924.

“Svenskan som blev drottning på en Söderhavsö”. Husmodern, I6 June 1935 .

Varisco, Daniel Martin, Reading Orientalism. Said and the Unsaid. Seattle: University of Washington Press, 2007.

Youngs, Tim. The Cambridge Introduction to Travel Writing. Cambridge: Cambridge University Press, 2013.

Zumthor, Paul and Catherine Peebles. "The Medieval Travel Narrative". New Literary History 25, no. 4 (I994): 809-24. 